INTERNATIONAL HIGHER EDUCATION, Number 72. Summer 2013

Pages 10-12

\title{
Financial Aspects of Offshore Activities
}

\author{
JOHN FIELDEN
}

John Fielden is director of the Commonwealth Higher Education Management Service Consulting, a small independent consultancy based in Odiham, Hampshire, in the UK. E-mail: johnfielden1@btinternet.com.

In April 2013 it was announced that the University of East London would close its new campus in Cyprus, after operating for only six months with an enrollment of just 17 students. In so doing, it joined the 11 closures of offshore campus ventures in the two years (2010-2012), recorded by the Observatory on Borderless Higher Education. These statistics emphasize the risky nature of offshore activities by universities and colleges. It is not just international branch campuses that are volatile; Australian transnational education operations have also fluctuated dramatically, falling from a peak of 1,569 programs delivered in other countries in 2003 to 889 in 2009. Despite these reverses, the growth in offshore provision continues remorselessly in some countries; in the United Kingdom, for example, in 2011/12 there were 571,000 international students studying for UK awards outside the United Kingdom, an increase of 40 percent on the figure two years before.

For members of university boards and senior managers the need for rigorous analysis of potential offshore activity has never been greater. They will be helped by a study from the United Kingdom's Higher Education International 
Unit—a guide to the financial aspects of UK offshore activities. This study sets out some of lessons learned by 24 universities in the United States, Australia, and the United Kingdom. Those interviewed were understandably reluctant to reveal too much about the financial consequences of their operations but were only too happy to pass on advice and recommendations to others. These have been encapsulated in the report under three headings: those at the early stage of entering into a Memorandum of Understanding; those when things are getting more serious and a legal agreement is required; and those at the operational stage when activities are underway.

\section{Signing a Memorandum OF Understanding}

The origins of these memorandums may hold the key to future success. Until recently they have been regarded by some as trophies collected at conferences or even a performance indicator of internationalization; some regard them as "a license to start talking," rather than any serious indication of collaboration. The interviews identified a trend to a more strategic approach. Major institutions are now investing research effort in identifying favorable countries and suitable partner institutions within them. In some cases, this fits within a strategy of having a limited number of significant "deep partnerships" for research and teaching in a small number of countries. This has led to a new-growth industry, developing country profiles backed by extensive due diligence on their currency, regulatory frameworks, tax regimes and incentives, national quality-assurance agencies, and legal requirements for the operation of higher education institutions. 
The word "values" is increasingly used when making decisions about foreign ventures. This applies particularly to the choice of partner. If the initiative comes from a government that will be the partner, this can be a sensitive issue; two major UK institutions-the University College London and the University of Westminster-have contracts for the delivery of higher education with the governments of Kazakhstan and Uzbekistan, which are not notable democracies. Both have taken great care to protect their reputation in their contracts. When choosing a commercial partner the problems are even greater, since many countries have financial and corporate accounting systems that are not very transparent. Commercial partners are often large conglomerates with property interests and see a university either as an attraction in a business development or as an emblem of corporate social responsibility. Even in such cases, however, the profit motive may not have gone away, and any difference of motive with the university can be a source of future discord.

\section{Developing a Business Case}

The second stage of activity involves the development of a business case for the board and a subsequent legal agreement. It is at this stage that common values and motives are essential with early agreement on tuition-fee levels, scholarships, and a reasonable period of payback. Another key issue, once the technical studies are underway, is having a common language and understanding, since informal relationships in the operational phase will thrive if there is a personal positive chemistry between the partners' leading players. Whatever the legal agreements say, unexpected occurrences and midterm 
corrections will be inevitable. An American interviewee said "anyone who has low tolerance for surprises, ambiguity and frequent shifting shouldn't even think about offshore operations." Cultural difficulties often arise in the negotiation phase. In some countries, the final legal agreement is regarded as the starting point for negotiation, and key definitions of words such as "students" or "surplus" are particularly prone to misinterpretation. A "yes" can mean "I hear you," rather than "I agree."

Other major topics in negotiations are the percentage share in any local holding company that is created to operate an offshore campus and the terms of an exit strategy. Since few universities are able (for fiduciary or legislative reasons) to invest large sums in overseas operations, the most common role of a commercial partner is to provide the physical infrastructure and sometimes the equipment. The argument then centers on the financial value of the intellectual property and brand of the incoming university, which will be used to calculate its share of any surplus or deficit. This becomes a haggle and can even result in world-class institutions-such as, the University of Nottingham having to accept stakes of 37.1 percent and 29.1 percent in the associate companies running its two offshore campuses. In discussions, offshore providers have decided that it is essential to think early and hard about the terms of an exit strategy; in some cases, this is even considered at the Memorandum of Understanding stage in case it becomes a deal breaker. 


\section{Managing Offshore ACtivities}

Once an offshore activity is up and running, the key question is where decisions are made and what is delegated to a local board or an academic partner. Most international branch campuses are owned by a local joint company with a board that takes the key decisions, while most transnational education operations have no local legal entity behind them and are managed by the home institution's academic structures. The most important decisions relate to admissions criteria (and consequential student numbers), local marketing strategies, and the level of tuition fees. This is when an early investment in building good personal relationships pays off. A commercial partner will be tempted to lower entry standards, adopt aggressive local marketing campaigns, and increase tuition fees, while the university will not.

Few offshore ventures make significant financial surpluses and many take between 5 to 10 years to see a return on investment. However, there are examples of reasonable financial benefits, and the research found that the most successful Australian universities claim to have average profit margins of 8 to 10 percent. But a key question is the cost base on which the 10 percent is calculated, since such a return is unlikely if all management and staff time is fully charged to the venture. Many of the universities in the sample claimed that it was not their aim to make financial surpluses but to promote their reputation in the region, to develop collaborative research with the partner or in the country, and to generate a flow of postgraduates back to the home campus.

Although the study has emphasised the importance of rigorous processes for due diligence and financial planning with comprehensive research about 
markets, a key conclusion is that these are not enough. Successful offshore operations demand good leadership and personal skills and mutually trusting relationships between the partners. If these exist, the unanticipated events and upheavals that will inevitably arise can be overcome. 